zur Hausen, H., Hildemann, S., Holgate, S., Holt, P., Jakob, T., Jung, A., Kemeny, M., Koren, H., Leung, D., Lockey, R., Marone, G., Mempel, M., Menné, B., Menz, G., Mueller, U., von Mutius, E., Ollert, M., O’Mahony, L., Pawankar, R., Renz, H., Platts-Mills, T., Roduit, C., Schmidt-Weber, C., Traidl-Hoffmann, C., Wahn, U. and Rietschel, E. (2012). Davos declaration: allergy as a global problem. Allergy, 67, 141143.

Ritenberga, O. (2017). Forecasting the geospatial and temporal patterns of pollen season in Europe using statistical and deterministic modelling. Riga: University of Latvia. https://dspace.lu.lv/dspace/handle/7/37532

Ritenberga, O., Sofiev, M., Kirillova, V., Kalnina, L. and Genikhovich, E. (2016). Statistical modelling of non-stationary processes of atmospheric pollution from natural sources: Example of birch pollen. Agricultural and Forest Meteorology, 226-227.

Ritenberga, O., Sofiev, M., Siljamo, P., Saarto, A., Dahl, A., Ekebom, A., Sauliene, I., Shalaboda, V., Severova, E., Hoebeke, L., Ramfjord, H. (2018). A statistical model for predicting the inter-annual variability of birch pollen abundance in Northern and North-Eastern Europe. Science of the Total Environment, 615.

Šauliene, I., Šukiene, L., Daunys, G., Valiulis, G., Vaitkevičius, L., Matavulj, P., Brad, S., Panic, M., Sikoparija, B., Clot, B., Crouzy, B., Sofiev, M. (2019). Automatic pollen recognition with the Rapid-E particle counter: the first-level procedure, expercience and next steps (under review). Atmospheric Measurement Techniques.

Scheifinger, H., Belmonte, J., Buters, J., Celenk, S., Damialis, A., Dechamp, C., Garcia-Mozo, H., Gehrig, R., Grewling, L., Halley, J.M., Hogda, K.-A., Jager, S., Karatzas, K., Karlsen, S.-R., Koch, E., Pauling, A., Peel, R., Sikoparija, B., Smith, M., Galan-Soldevilla, C., Thibaudon, M., Vokou, D. and de Weger, L. (2013). Monitoring, modelling and forecasting of the pollen season. In: Sofiev, M. and Bergmann, K.-C. (eds.) Allergenic Pollen. 247.

Sofiev, M., Ritenberga, O., Albertini, R., Arteta, J. and Belmonte, J. (2017). Multi - model ensemble simulations of olive pollen distribution in Europe in 2014. 1-32.

\title{
LANDSCAPE OF SEMI-WILD LARGE HERBIVORES IN THE SPECIALLY PROTECTED NATURE TERRITORIES OF LATVIA
}

\section{Lielie pussavvaḷas zālēdāji īpaši aizsargājamās dabas teritorijās Latvijā}

\author{
Agnese Reķe, Anita Zariņa, Solvita Rūsiña \\ University of Latvia, Faculty of Geography and Earth Sciences \\ agnese.reke@gmail.com
}

\begin{abstract}
Semi-wild large herbivores have been present in the Latvian landscape now for just on 20 years. Nevertheless, the available information about the already implemented introduction projects is scattered and fragmentary. The aim of this paper is to outline and discuss the landscape of semi-wild animal grazing projects in the specially protected nature territories (SPNT) throughout Latvia, focusing on the project implementation contexts, locational factors and current management issues. The results of this study show that grazing areas of semi-wild herbivores are located mainly in nature parks and nature reserves. The typical location for the establishment of a grazing site is a former agricultural land area that has been abandoned by its previous users due to unsuitable conditions for profitable agricultural activity and which is located close to a natural waterbody. The main goal for all of the analyzed introduction projects was the restoration and protection of open landscape and grassland habitats. According to the research results, at
\end{abstract}


present, the main problem regarding grazing sites of semi-wild large herbivores, is the existing policy framework. This study raises many questions about the future of semi-wild herbivores in Latvia and these should be addressed in further in-depth studies.

Keywords: semi-wild large herbivores, grazing animal landscape, introduction, re-wilding, natural grazing

\section{Introduction}

Large herbivores had an important role in shaping the natural landscape of Europe in the pre-agrarian period. By the allowing of grazing they maintained the natural grasslands, influenced the species composition in habitats of their surroundings and by uprooting the smaller trees and de-barking the larger ones, they even changed the closed forests on a local scale (Vera 2000; Vera et al. 2007; Vermeulen 2015) - a habitat that, according to traditional succession theories (see Clements 1916), is the final stage of vegetation succession in lowland Europe. Due to the development of farming and over-hunting, the number of wild large herbivores in Europe rapidly decreased - some species were driven out of their surroundings to more remote territories, other species became extinct. The species that completely vanished from European nature were wild horses (Equus ferus) or tarpans and wild cattle (Bos primigenius) or aurochs - the last known auroch died in 1627 in Poland and the last tarpan in 1887 in Ukraine (Vermeulen 2015).

Around the 1920-30s, scientists created two new herbivore breeds through crossbreeding of existing primitive cattle and horse breeds. The two new breeds were Heck cattle and Konik polski horses which resembled the extinct aurochs and tarpans by appearance and had the capability to survive in the wild. After the creation of these new herbivore breeds, the idea of introducing them into the wilderness was born (Lorimer and Driessen 2013; Vermeulen 2015). According to the research of some well-recognized authors (Vera 2000; Vermeulen 2015), the (re)introduction of large herbivores in the European landscape is a fundamental part of restoring the natural balance of eco-systems or 're-wilding' - a term that is largely used to describe the restoration of natural processes (Jorgensen 2015; Vermeulen 2015). One might ask the question that, amongst all the other herbivore species that did not become extinct, why bother with wild cattle and horses? As a matter of fact, it is a widely held view that each of the indigenous large herbivore species in Europe had its own role in the ecosystem that cannot be overtaken by other species (Vermeulen 2015). The basic idea of introducing animal species that resemble the extinct herbivores, was to replace the missing grazing animals in the landscape, so they can participate in the creation of landscapes once again (Kugler and Broxham 2014; Vermeulen 2015). Probably the best known introduction project is the Oostvaardersplassen in the Netherlands - at the beginning of the 1980s, the Dutch scientist Frans Vera commenced an experiment in the Oostvaardersplassen polder by introducing Heck cattle, Konik polski and other large herbivores in the territory to 're-wild' the landscape of Oostvaardersplassen. After Vera's experiment, the idea of introducing large herbivores gained popularity 
and these introduction projects gradually spread all over Europe (Lorimer and Driessen 2013).

In Latvia, the first large herbivores were introduced in 1999 at the Nature Park "Pape" as a part of WWF Latvia's project that aimed to restore the natural habitats in the Pape polder - a former agricultural territory (Zarina et al. 2018). However, even though just on 20 years have passed since the first introduction project and at the time the project was controversially received (Schwartz 2005; Schwartz 2006; Zarina and Treija 2015), there has still been no in-depth analysis and/or discussions made available for study. Most of the studies done thus far focus only on particular aspects of these grazing projects, for example, changes in vegetation of the grazing sites (Mednis 2008; Gruberts and Strausa 2011), the attitudes of society (Schwartz 2005; Zarina and Treija 2015) or the emergence of post-productivist ideas in the former agricultural lands of Latvia (Zarina et al. 2018).

Thus, the aim of this paper is to outline and discuss the landscape of semi-wild animal grazing projects in the specially protected nature territories (SPNT) of Latvia, focusing on the various project implementation contexts, locational factors and current management issues.

We used field observations, interviews, analyses of literature and documents to understand the geography and time-line of the introduction projects, as well as to create a database consisting of the accounts of introduced animal species, initial and current size of animal populations, geographic location, size of grazing areas and landscape characteristics. Our fieldwork was conducted in 2018, when we visited altogether 4 grazing areas. We conducted 8 semi-structured interviews with park managers and experts. The interviews were conducted in 2018 and 2019.

\section{Semi-wild herbivore grazing sites in specially protected nature territories of Latvia}

The grazing areas of semi-wild large herbivores of SPNT are situated in geographically different locations (Figure 1), all of which were established from 1999 to 2007 (Figure 2), mainly in nature parks and nature reserves. Since 2007 no new semi-wild grazing areas have been established. According to the conducted interviews, the main reason for this phenomenon might be the issue of insufficient funding - most of the grazing sites were established with the financial support of various nature conservation projects. Since the project conclusion, the main source of funding for maintenance of the grazing sites consists only of subsidies, which, according to the interviewed managers of the grazing sites, do not cover all the costs. Another factor is the lack of grassland territories that are large enough for the establishment of grazing sites. However, this aspect requires further in-depth study.

All of the cases bear a similar objective - the protection and restoration of mosaic landscape and grasslands. Another significant trait, common to almost all of the cases, is their link to the internationally significant bird breeding, nesting and 
wintering sites. Therefore, the aim of restoring the mosaic landscape is partly connected to the needs of bird species conservation and management.

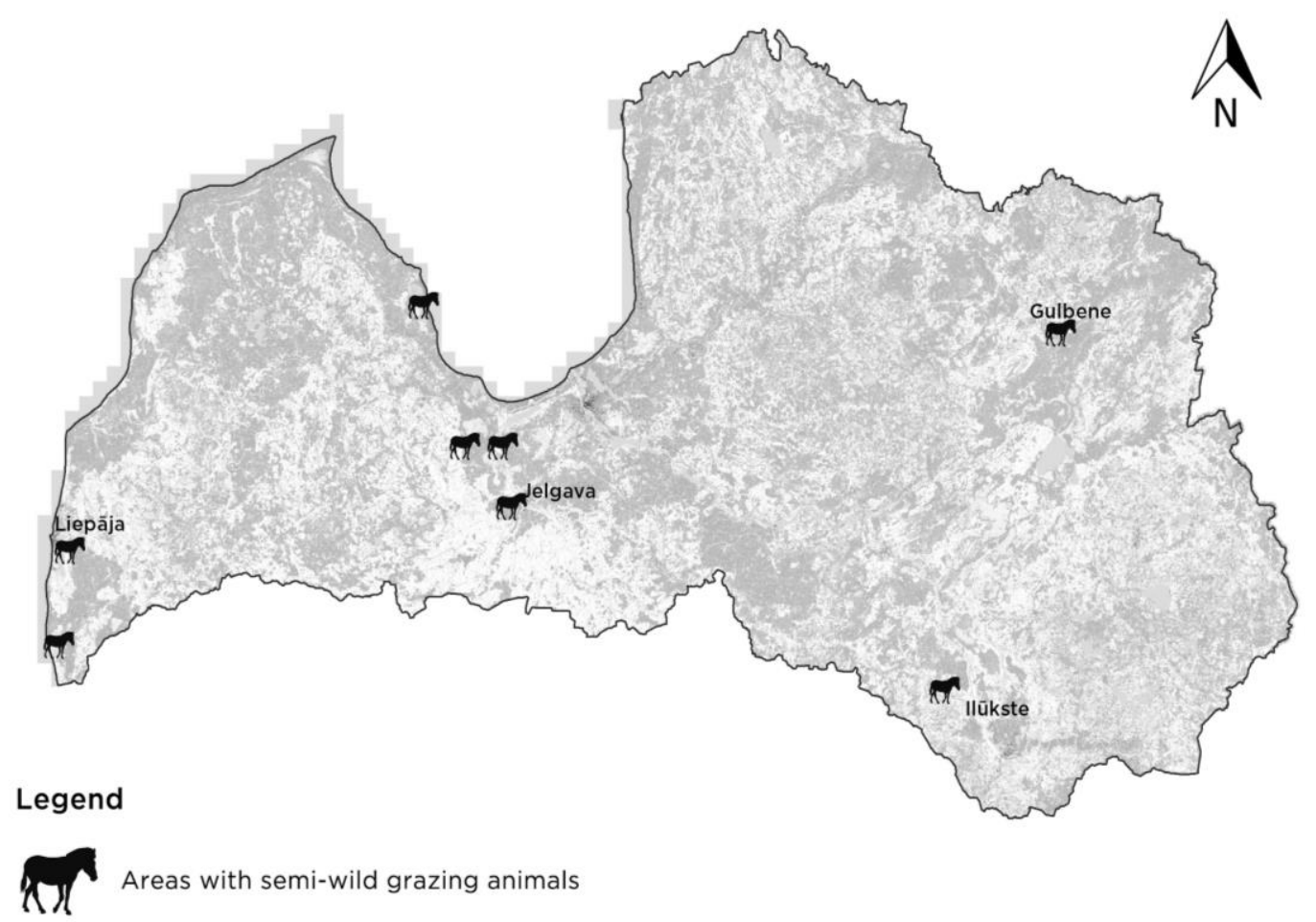

Figure 1. The spatial distribution of semi-wild large herbivore grazing sites in SPNT of

Latvia (authors' figure based on data from kartes.geo.lu.lv, topographical map M:10 000 LGIA)

Currently the area of semi-wild grazing territories in SPNT throughout Latvia ranges from less than 100 ha to 400 ha (see Table 1). The largest grazing areas are located in the Nature Park "Pape" and the Nature Park "Dviete Floodplain". According to research results, the number of semi-wild herbivores has significantly increased since the establishment of grazing areas in all introduction sites (see Table 1). There are two main reasons for this. Firstly, in the initial stages of the introduction projects, new animals were added to the herds for larger genetic variation as limited variation of genes may lead to weaker population (see Vermeulen 2015). Secondly, the natural population increase - the number of live births thus far is larger than the number of deaths. However, the significant growth of populations raises the question of overpopulation (Nolte et al. 2014; Moseby et al. 2018). The question of optimal population density should be addressed in future studies. 


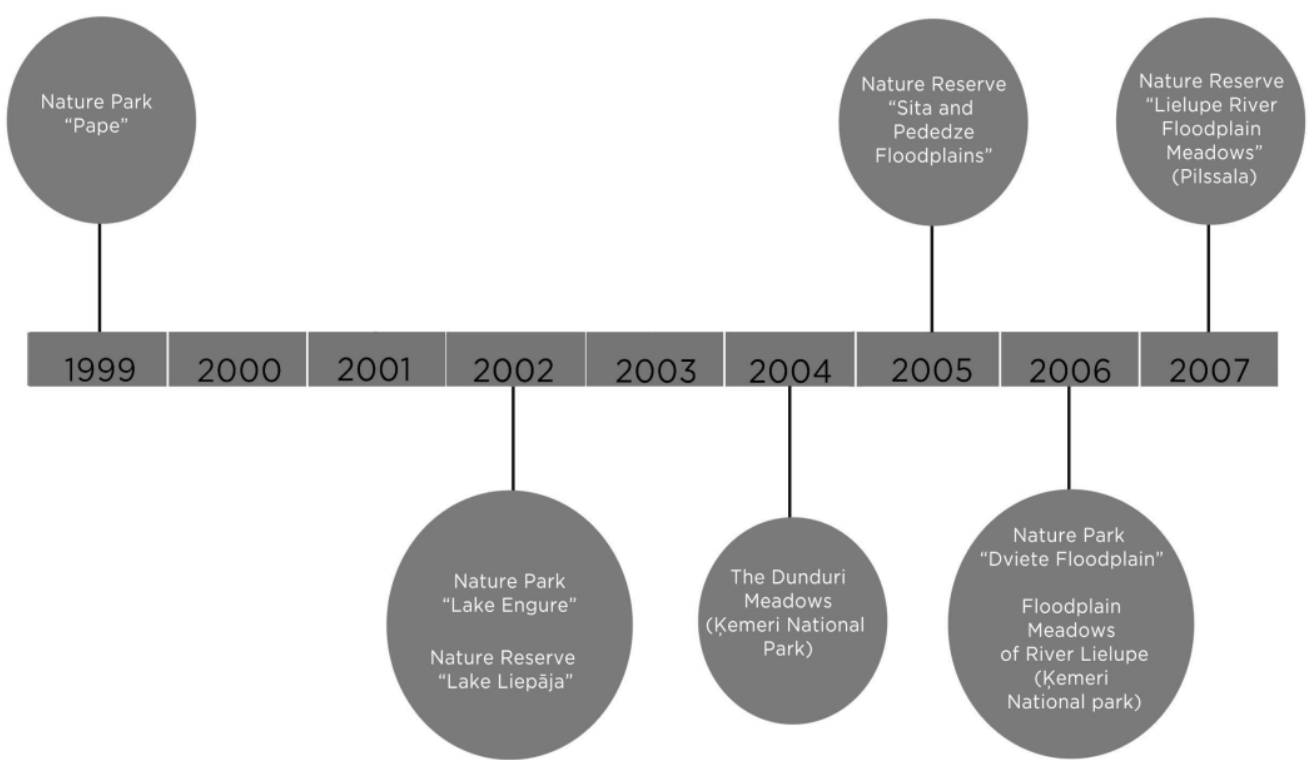

Figure 2. Time-line of introduction projects in SPNT of Latvia (authors' figure)

Table 1. The semi-wild large herbivore grazing sites in SPNT of Latvia

\begin{tabular}{|c|c|c|c|c|c|}
\hline & $\begin{array}{l}\text { Type of } \\
\text { protected } \\
\text { nature } \\
\text { area }\end{array}$ & $\begin{array}{c}\text { Type of } \\
\text { introduced } \\
\text { herbivores }\end{array}$ & $\begin{array}{c}\text { Initial } \\
\text { number of } \\
\text { introduced } \\
\text { herbivores }\end{array}$ & $\begin{array}{c}\text { Current number of } \\
\text { large herbivores } \\
(\mathbf{2 0 1 8})^{*}\end{array}$ & $\begin{array}{l}\text { Size of the } \\
\text { grazing } \\
\text { area, ha } \\
(2018)\end{array}$ \\
\hline Pape & Nature park & $\begin{array}{l}\text { Semi-wild } \\
\text { horses and } \\
\text { cattle, } \\
\text { European } \\
\text { bison }\end{array}$ & $\begin{array}{l}18 \text { horses, } 23 \\
\text { cattle, } 5+12 \\
\text { bison }\end{array}$ & $\begin{array}{l}100 \text { cattle, } 100 \\
\text { horses, } \\
5 \text { bison known } \\
\text { (escaped from the } \\
\text { enclosure in 2009) }\end{array}$ & 400 \\
\hline Lake Engure & Nature park & $\begin{array}{l}\text { Semi-wild } \\
\text { horses and } \\
\text { cattle }\end{array}$ & $\begin{array}{l}5 \text { cattle, } 6 \\
\text { horses }\end{array}$ & 50 cattle, 6 horses & 100 \\
\hline Lake Liepāja & $\begin{array}{l}\text { Nature } \\
\text { reserve }\end{array}$ & $\begin{array}{l}\text { Semi-wild } \\
\text { horses and } \\
\text { cattle }\end{array}$ & $\begin{array}{l}8 \text { cattle, } 10 \\
\text { horses }\end{array}$ & 40 cattle, 20 horses & 140 \\
\hline $\begin{array}{l}\text { Kemeri (The } \\
\text { Dunduri } \\
\text { Meadows) } \\
\end{array}$ & $\begin{array}{l}\text { National } \\
\text { park }\end{array}$ & $\begin{array}{l}\text { Semi-wild } \\
\text { horses and } \\
\text { cattle }\end{array}$ & $\begin{array}{l}15 \text { cattle, } 10 \\
\text { horses }\end{array}$ & 69 cattle, 99 horses & 180 \\
\hline $\begin{array}{c}\text { Sita and } \\
\text { Pededze } \\
\text { Floodplains } \\
\end{array}$ & $\begin{array}{l}\text { Nature } \\
\text { reserve }\end{array}$ & $\begin{array}{l}\text { Semi-wild } \\
\text { horses and } \\
\text { cattle }\end{array}$ & $\begin{array}{l}23 \text { cattle, } 20 \\
\text { horses }\end{array}$ & information $\mathrm{n} / \mathrm{a}$ & 250 \\
\hline $\begin{array}{c}\text { Dviete } \\
\text { Floodplain }\end{array}$ & Nature park & $\begin{array}{l}\text { Semi-wild } \\
\text { horses and } \\
\text { cattle }\end{array}$ & $\begin{array}{l}17 \text { cattle, } 13 \\
\text { horses }\end{array}$ & 130 cattle, 50 horses & 400 \\
\hline $\begin{array}{c}\text { Kemeri } \\
\text { (Floodplain of } \\
\text { River Lielupe) } \\
\end{array}$ & $\begin{array}{l}\text { National } \\
\text { park }\end{array}$ & $\begin{array}{l}\text { Semi-wild } \\
\text { horses and } \\
\text { cattle }\end{array}$ & $\begin{array}{l}15 \text { cattle, } 10 \\
\text { horses }\end{array}$ & 74 cattle, 67 horses & 280 \\
\hline $\begin{array}{c}\text { Pilssala } \\
\text { (Floodplain } \\
\text { Meadows of } \\
\text { River Lielupe) } \\
\end{array}$ & $\begin{array}{l}\text { Nature } \\
\text { reserve }\end{array}$ & $\begin{array}{l}\text { Semi-wild } \\
\text { horses }\end{array}$ & 16 horses & 71 horses & 70 \\
\hline
\end{tabular}

* approximate number, according to managers of grazing sites 


\section{Landscapes of semi-wild herbivores grazing areas}

According to the historical cartographic materials, all of the semi-wild herbivore grazing sites are located in former agricultural lands - abandoned arable lands and grasslands. This aspect indicates the adaptation to post-productivist management practices in the agriculturally marginal areas that used to be part of the productivist agriculture system (Zarina et al. 2018). Some of the semi-wild herbivore grazing sites include forest areas and bogs as well, for example, in the Nature Park "Lake Engure" and in the Dunduri Meadows of the Kemeri National Park. All of the territories are characterized by wet conditions and the presence of rivers or lakes. This trait might be explained by several reasons. Firstly, the presence of wet conditions suggest, that these territories are not suitable for economically profitable agricultural activity and therefore were abandoned by previous users. Secondly, the wet floodplain meadows - in such areas grazing is considered to be more effective than mechanical management. Thirdly, the presence of natural waterbodies enables the availability of drinking water for animals.

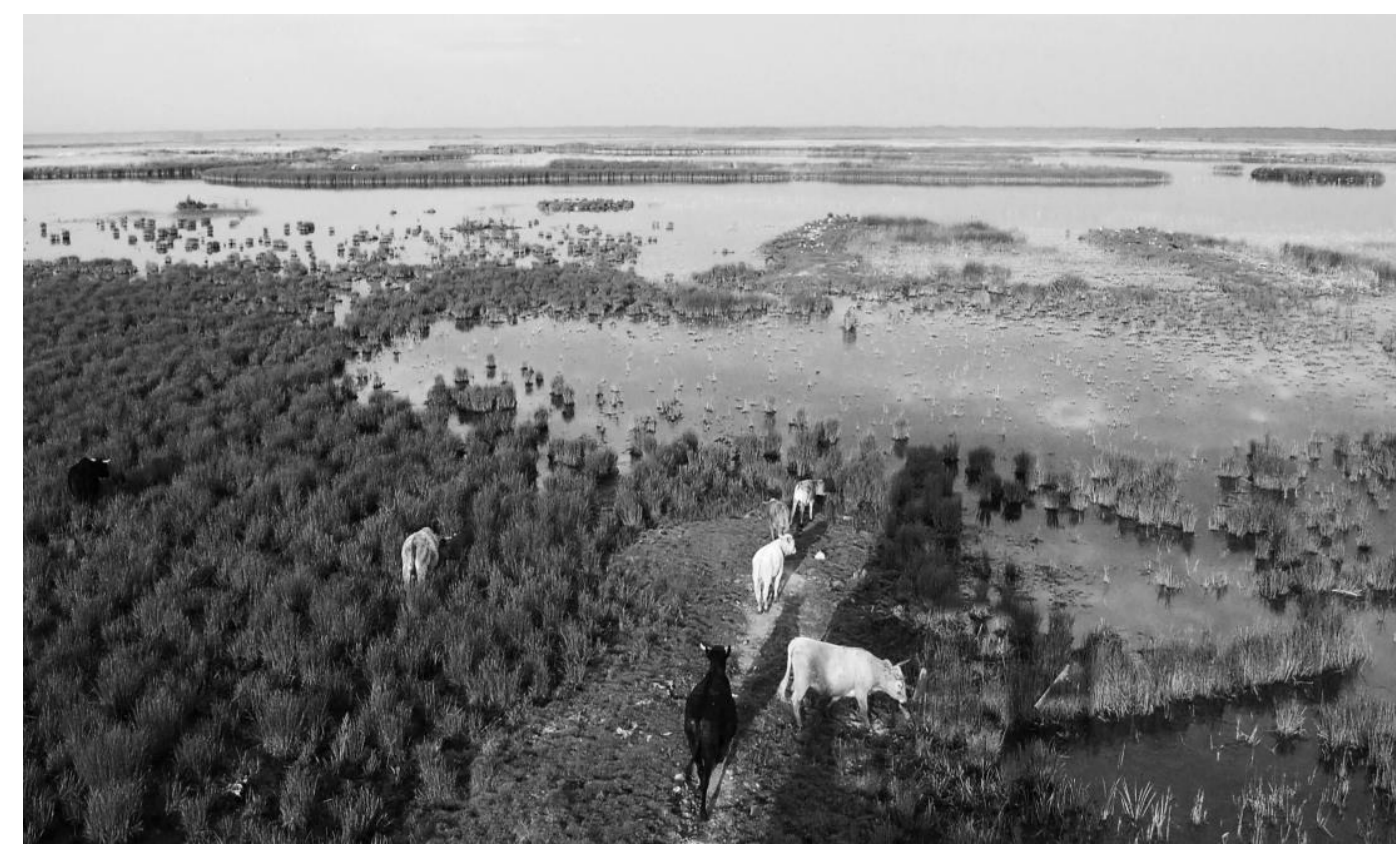

Figure 3. Landscape of the grazing site at the Nature Park “Lake Engure”" (authors' figure)

The analysis of orthophoto maps shows that since the introduction of semi-wild herbivores the landscapes of grazing areas have changed - the shrub coverage of grasslands has decreased and the landscape has become more open (Figure 4). Although further research is required, the preliminary observations indicate that the introduction of semi-wild large herbivores is successful regarding the aspect of landscape maintenance. 

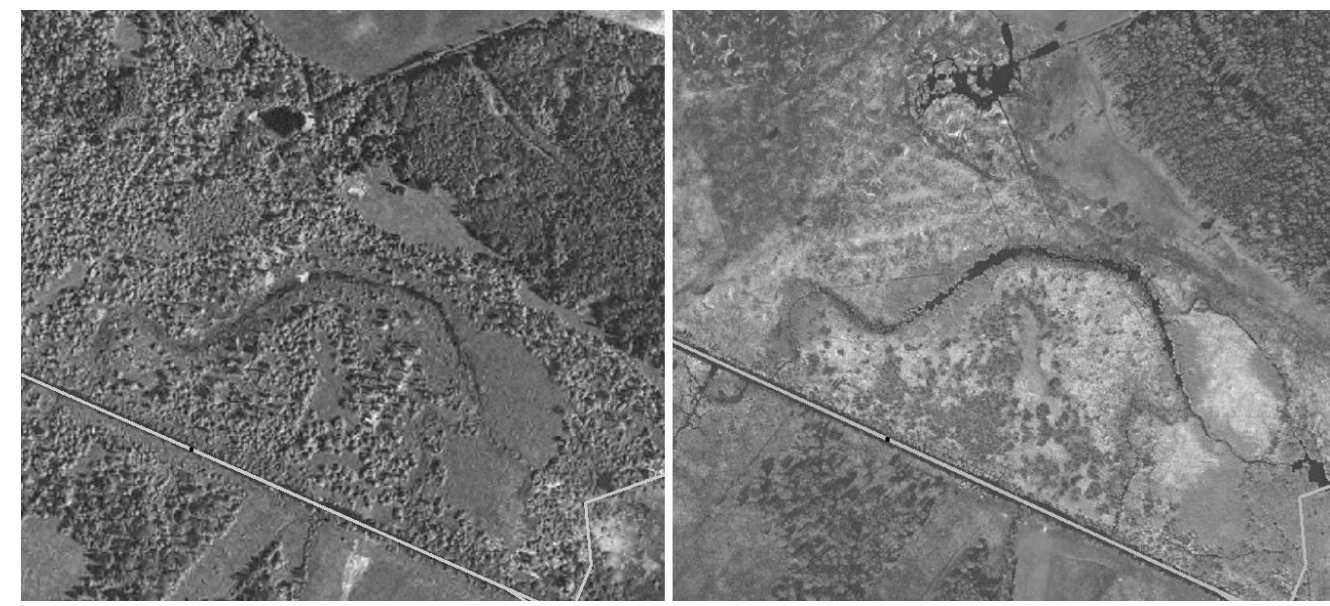

Figure 4. Grazing area in the Nature Park "Dviete Floodplain": changes in the landscape from 1995 (left) to 2014 (right) (authors' figure based on orthophoto maps from kartes.geo.lu.lv)

\section{Management of semi-wild herbivore grazing sites}

There are two very different approaches to the management of semi-wild large herbivore populations (Kugler and Broxham 2014). In one approach, the introduced animals are considered to become a natural part of landscape and the main goal of their introduction is to recreate the natural balance of ecosystems as it was in the preagrarian era. In the other approach, the introduced animals are considered to be just an alternative means for grassland habitat management. The former represents the implementation of Western wilderness values, while the latter is related to protection of specific species and habitats according to place-based nature protection goals. The different management models are directly connected to the main problem regarding semi-wild animal populations in Latvia - legal framework. According to interviews with the managers of the grazing sites, the current legal framework classifies semiwild herbivores as livestock and therefore they are subject to the same regulations. The interviewed managers state that the current laws are not compatible with the approach that sees the introduced animals as a part of the natural landscape, because the fulfillment of requirements (ear tagging or chipping of animals, blood and milk analysis etc.) requires regular contact with humans. This means that the animals cannot develop their natural behaviour and integrate into the ecosystem. The interviewed managers of grazing sites suggest that changes in the legal framework should be considered.

On the other hand, the responsible authorities state that the existing legal framework is necessary as the introduced grazing animals live in fenced areas and their welfare depends on the activities of the grazing site managers. Secondly, the introduction of grazing animals is linked to a greater risk of the transmission of diseases and other problems that can be avoided by human supervision. However, the case of Latvia is not to be considered unique. Studies show (see Vermeulen 2015; Rewilding Europe 2019) that the discussion about legal framework regarding semiwild grazing animals is topical in other European countries as well. 


\section{Conclusion}

According to the authors (Vera 2000; Vera et al. 2007; Vermeulen 2015), the (re)introduction of large herbivores in the European landscape is a fundamental part of restoring the natural balance of ecosystems. In Latvia the first semi-wild large herbivores were introduced in 1999 at the Nature Park "Pape". Since then, pastures of semi-wild large herbivores have been established in various SPNT, mainly in nature parks and nature reserves. The most popular herbivore breeds for introduction are Konik polski horses and Heck cattle, but other similar crossbreeds are present in the grazing areas as well. All of the grazing sites are located in the former arable lands and grasslands.

The conducted interviews elucidated legal framework as the main issue regarding the management of semi-wild grazing animal populations. According to current laws, semi-wild grazing animals are classified as livestock. The interviewed managers of grazing sites state that the laws should be modified and legal exceptions for semi-wild animals should be made in order to fit the actual situation - the semiwild animals are not used to regular human presence, therefore meeting the current legal requirements is almost unattainable.

The results of this study raise a number of questions that should be addressed in further situational explorations. Firstly, the question of legal framework - the opinion of different stakeholders should be analyzed, as well as case studies of semi-wild large herbivore grazing sites should be conducted to evaluate advantages and disadvantages of different management approaches. Results of such studies would provide crucial information for possible legal framework improvements. Secondly, the time dimension of the introduction projects. Results show that no new semi-wild herbivore grazing areas have been established since 2007. According to the interviews, this might be linked to insufficient subsidies and the lack of suitable territories for the establishment of pastures. However, this aspect requires further in-depth study. Thirdly, the semi-wild herbivore populations themselves - there are still many unanswered questions regarding optimal population densities and population dynamic. Finally, landscapes of semi-wild herbivores. In-depth studies about the landscape changes, society's perception of the new rural landscapes with the presence of large herbivores and the role of herbivores in Latvia's landscape should be undertaken.

\section{Kopsavilkums}

Latvijā pirmie pussavvaḷas lielie zālēdāji tika ieviesti jau 1999. gadā dabas parkā „Pape”, taču informācija par Latvijā īstenotajiem introdukcijas projektiem joprojām ir nepiln̄̄ga. Šis pētījums ir veikts, lai apkopotu un analizētu informāciju par introducēto pussavvaļas zālēdāju ganībām īpaši aizsargājamās dabas teritorijās (İADT) Latvijā, akcentējot projektu ieviešanas kontekstu, ganību ǵeogrāfiskā novietojuma faktorus un pašreizējās apsaimniekošanas problēmas. Pētijumā analizētas 8 ievērojamākās pussavvaḷas zālēdāju ganības İADT. Pētijumā noskaidrots, ka visas analizētās ganības ir ierīkotas vietās, kas pēc vairākām pazīmēm ir savstarpēji līdzīgas - tās atrodas bijušajās lauksaimniecības zemēs, ko raksturo ūdeņu (ezera vai upes) klātbūtne, pārmitri apstākḷi un retas biotopu vai putnu sugas. Cita iezīme, kas līdzīga visiem analizētajiem projektiem, bija formulētais introdukcijas mērḳis - mozaīkveida ainavas un 
zālāju biotopu uzturēšana. Kopumā iegūtie rezultāti nodrošina būtisku informācijas bāzi turpmākajiem pētījumiem.

Pētījumā veiktās intervijas parādīja, ka pašlaik galvenā problēma pussavvaḷas zālēdāju ganību uzturēšanā ir spēkā esošie likumi, kas pussavvaḷas zālēdājus klasificē kā mājlopus, līdz ar to pakḷaujot tos tādām pašām likumdošanas prasībām. Pēc ganību apsaimiekotāju domām, būtu jāveic likumu grozījumi, lai tos pielāgotu reālajai situācijai. Interešu konflikts starp atbildīgajām valsts instancēm un ganību apsaimniekotājiem ir viens no jautājumiem, kam plānots pievērst uzmanību turpmākajos pētījumos. To rezultāti iezīmēja arī citus pussavvaḷas zālēdāju ganību aspektus, kam būtu nepieciešams pievērsties turpmākajos pētījumos, to skaitā ainavu pārmaiṇām ganību teritorijās un introducēto zālēdāju lomai un tās uztverei Latvijas lauku ainavā.

\section{References}

Birks, H.J.B. (2005). Mind the gap: how open were European primeval forests? Trends in Ecology and Evolution, 20 (4), 154-156.

Clements, F.E. (1916). Plant Succession. An Analysis of the Development of Vegetation. Washington: Carnegie Institution, 62-67.

Gruberts, D. and Štrausa, B. (2011). A cooperational model of year-round grazing for the benefits of farmers and floodplain habits: an example from the Dviete Floodplain Nature Park. In: Reihmanis, J. (ed.) Nordic-Baltic-Belarus solutions in farming for biodiversity. Rìga: Latvian Fund of Nature, 62-81.

Hobson, K. (2007). Political animals? On animals as subjects in an enlarged political geography. Political Geography, 26 (3), 250-267.

Jorgensen, D. (2015). Rethinking rewilding. Geoforum, 65, 482-488.

Kugler, W. and Broxham, E. (2014). The ecological value of feral livestock populations in Europe. Switzerland: SAVE Foundation, 27.

Lorimer, J. and Driessen, C. (2013). Bovine biopolitics and the promise of monsters in the rewilding of Heck cattle. Geoforum, 48, 249-259.

Mednis, A. (2008). Pḷavu biotopu kā putnu dz̄ives vietas atjaunošana Engures ezera dabas parkā 2003.-2007.gadā. In: Auniņš, A. (red.) Aktuālā savvaḷas sugu un biotopu apsaimniekošanas problemātika Latvijā. Rīga: Latvijas Universitāte, 101-110.

Moseby, K.E., Lollback, G.W. and Lynch, C.E. (2018). Too much of a good thing: successful reintroduction leads to overpopulation in a threatened mammal. Biological Conservation, 219, 78-88.

Nolte, S., Esselink, P., Smit, C. and Bakker, J.P. (2014). Herbivore species and density affect vegetation-structure patchiness in salt marshes. Agriculture, Ecosystems \& Environment, 185, 41-47.

Pasaules dabas fonds. (2004). Lielo savvaḷas zālēdāju dabiskā ganīšanās. http://assets.wwflv.panda.org/downloads/lielo_savvalas_zaledaju_gramata.pdf (03.01.2019).

Rewilding Europe. (2019). Rewilding Europe to coordinate new LIFE project on grazing management models. https://rewildingeurope.com/news/rewilding-europe-to-coordinate-new-lifeproject-on-grazing-management-models/ (25.01.2019)

Schwartz, K. (2006). Nature and National Identity after Communism. Globalizing the Ethnoscape. Pittsburgh: University of Pittsburgh Press.

Schwartz, K. (2005). Wild horses in a 'European wilderness': imagining sustainable development in the post-Communist countryside. Cultural Geographies, 12 (3), 292-320.

Vera, F. (2000). Grazing Ecology and Forest History. Wallingford: CABI.

Vera, F., Buissink, F., Weidema, J. (2007). Wilderness in Europe: What really goes on between the trees and the beasts? Netherlands: Tirion Natuur, 199.

Vermeulen, R. (2015). Natural grazing: Practises in rewilding of cattle and horses. Netherlands: FREE Nature, 40.

Zarina, A. and Treija, D. (2015). Becoming bison: the precedent of wilderness in the Latvia ethnoscape. Landscape Wilderness and the Wild. Conference program and full papers, 254-257. 
Zariņa, A., Vinogradovs, I. and Šķiņķis, P. (2018). Towards (dis)continuity of agricultural wetlands: Latvia's polder landscapes after Soviet productivism. Landscape Research, 43 (3), 455-469.

Watt, A.S. (1947). Pattern and process in plant communities. Journal of Ecology, 35 (1/2), 1-22.

\title{
NATURE CENSUS - THE FIRST DETAILED, SCIENTIFICALLY-GROUNDED INFORMATION ABOUT LATVIA'S NATURE VALUES
}

\section{Dabas skaitīšana - pirmā detalizētā un zinātniski pamatotā informācija par Latvijas dabas vērtībām}

\author{
Arta Krūmiṇa, Jānis Kotāns, Jānis Puga, Ilze Reinika, Gita Strode \\ Nature Conservation Agency of Latvia \\ arta.krumina@daba.gov.Iv
}

\begin{abstract}
The purpose of this article is to analyse the importance of major inventories of nature values the mapping of habitats of EU importance - in the context of introducing and implementing a nature conservation policy in compliance with the necessity to integrate the requirements of those EU directives concerning specially protected nature areas into the governance system of Latvia. This paper examines the inventory of nature values from different perspectives - the introduction and implementation of policy, cross-sector co-operation and the integrity of national natural resource databases.
\end{abstract}

Keywords: nature conservation, implementation of EU directives, sustainable development for natural values, Latvia

\section{Introduction}

Until 2014, only $10 \%$ of Latvian territory had been made accessible to the distribution maps of the protected species and habitats of European Union (further in the text - EU) importance. The main part of this data consisted of information about the already mapped special areas of conservation. Moreover, in most cases, this data was more than 5 years old. Such a situation had resulted during the recession (i.e., from 2008 to 2014), when financial resources for the monitoring of data related to nature were reduced significantly (Ministry of Environmental Protection and Regional Development 2013). The lack of voluminous and qualitative data influences the efficiency of nature - and environmental protection; it also has an adverse impact on Latvia's ability to maintain EU commitments and its ability to report on general environmental indicators and their changes in the entire territory of Latvia. Thus far, information about the habitat distribution of EU importance, and its occurrence in Latvia, has been based on an extrapolation of monitoring or other data, which does not reflect the situation at the level of specific areas, but rather provides an insight into the possible situation in the entire country. As a result of such data extrapolation, the occurrence of some habitats of EU importance in the country can possibly be assessed too pessimistically (i.e. without knowing the overall situation in the entire country, or about stricter limitations that are set for some types of habitats, thus unreasonably 